\title{
PENGEMBANGAN KURIKULUM MUATAN LOKAL SENI UKIR JEPARA SEBAGAI UPAYA KELESTARIAN
}

\author{
Miftahur Rizka Maulia Mahfudlo, Sulton, Saida Ulfa \\ Jurusan Teknologi Pendidikan, Fakultas Ilmu Pendidikan, Universitas Negeri Malang \\ Jalan Semarang 5 Malang Jawa Timur Indonesia \\ Email: rizkamaulia9@gmail.com
}

\begin{tabular}{|c|c|}
\hline Article History & Abstrak \\
\hline $\begin{array}{l}\text { Received:June, } 24^{\text {th }} 2019 \\
\text { Accepted: August, } 16^{\text {th }} 2019 \\
\text { Published: August, } 31^{\text {st }} \\
2019\end{array}$ & $\begin{array}{l}\text { Tujuan dari penelitian ini adalah menghasilkan produk kurikulum muatan } \\
\text { lokal seni ukir Jepara yang menjadi salah satu upaya untuk mengenalkan } \\
\text { potensi daerah jepara kepada siswa padajenjang SMP, sehingga dapat terjaga } \\
\text { kelestarian lokal daerah Jepara serta dapat menjadi generasi penerus yang } \\
\text { peduli untuk menjaga bahkan mengembangkan seni ukir Jepara. Metode } \\
\text { pengembangan yang menjadi pedoman adalah model pendekatan kompetensi } \\
\text { oleh Toenlioe (2017). Yang menjadi subjek penelitian adalah MTs Roudlotul } \\
\text { Ulum Suwawal Jepara. Data yang di gunakan adalah data kuantitatif, dari } \\
\text { Instrumen ahli kurikulum, ahli materi dan kualitatif dari observasi dan } \\
\text { wawancara. Hasil validasi kurikulum muatan lokal Seni Ukir dinyatakan valid. } \\
\text { Dengan perolehan presentase dari ahli materi mencapai } 90.88 \% \text { dan dari ahli } \\
\text { kurikulum mencapai 89.50\%. } \\
\text { Abstract } \\
\text { The purpose of this research is to produce a curriculum for local content in } \\
\text { Jepara carving which is one of the efforts to introduce the potential of Jepara } \\
\text { to students at junior high school level, so that local Jepara area can be } \\
\text { preserved and be able to become the next generation that cares to maintain } \\
\text { and even develop Jepara carving. The development method that becomes the } \\
\text { guideline is the competency approach model by Toenlioe (2017). The subject } \\
\text { of the study was MTs Roudlotul Ulum Suwawal Jepara. The data used are } \\
\text { quantitative data, from curriculum expert instruments, material experts and } \\
\text { qualitative observations and interviews. The results of the validation of the } \\
\text { Carving Art local content curriculum were declared valid. With the acquisition } \\
\text { of material experts reached } 90.88 \% \text { and from curriculum experts reached } \\
\text { 89.50\%. }\end{array}$ \\
\hline
\end{tabular}




\section{PENDAHULUAN}

Indonesia merupakan negara yang kaya, terbukti memiliki bermacam-macam suku bangsa, agama dan budaya. Dengan menjaga kelestarian dan memanfaatkan sebaik mungkin keanekaragaman multikultural yang ada, Indonesia dapat memperkaya kehidupan bangsa. Setiap daerah memiliki ciri khas atau kearifan lokal sebagai potensi daerah yang dapat dibanggakan.

Namun seiring perkembangan zaman kearifan lokal semakin pudar, karena tertindas budaya barat yang berkembang pesat di Indonesia. Misalnya, permainan-permainan tradisional yang kini tergantikan oleh game online. Pudarnya kebudayaan Indonesia juga mengakibatkan negara lain pernah mengklaim, seperti Batik, Lagu Rasa Sayange, Wayang Kulit, Reog Ponorogo dan lain-lain.

Menjaga kelestariannya merupakan upaya yang dapat dilakukan untuk menangani masalah ini, salah satunya adalah dalam dunia pendidikan, kurikulum muatan lokal misalnya. Kurikulum muatan local merupakan perencanaan pembelajaran untuk mengembangkan kompetensi sesuai dengan potensi daerah, dan sebagai upaya agar penyelenggaraan pendidikan disesuaikan dengan kebutuhan daerah yang bersangkutan.

Jepara merupakan kabupaten yang memiliki julukan khas yaitu sebagai Kota Ukir karena terkenal akan ukiran kayunya yang sudah terkenal hingga ke luar negeri. Sejak tahun 1960-an jepara mendapatkan predikat sebagai Kota Ukir, karena ukiran kayunya yang indah dan berkualitas. Tahun 2011 juga berhasil menyelesaikan rekor MURI dan rekor dunia dalam bidang mengukir kayu bersama paling banyak di dunia, hingga mendapat gelar "The World Carving Center" (Budiani, 2018). Seni Ukir Jepara memberi kontribusi besar dalam perekonomian masyarakat.

Seni ukir Jepara sudah menjadi penggerak ekonomi mata pencaharian warga yang berprofesi sebagai pengrajin ukir. Hal ini dapat dilihat banyaknya industri mebel yang menyebar di daerah Jepara, mulai dari tengah-tengah kota hingga beberapa desa di Jepara. Kemampuan mengukir diwariskan secara turun temurun dari generasi ke generasi (Nangoy \& Sofiana, 2013). Namun seiring perkembangan zaman, pengrajin ukir Jepara semakin berkurang, mereka mulai mengabaikan ukir dan harga ukiranpun semakin rendah, bahkan masyarakat jepara sendiri mualai tidak mengenal karya ukir itu sendiri (Budiani, 2018).

Permasalahan tersebut memberi kekhawatiran bahwa seni ukir Jepara sebagai potensi daerah, tidak ada yang mewarisi sehingga akan terancam punah. Untuk mencegah hal tersebut perlu adanya upaya untuk melestarikannya, salah satunya adalah melalui bidang pendidikan. Dengan pendidikan siswa mendapat pengetahuan seputar kearifan lokal yang akan dimuat pada kurikulum muatan lokal. Muktadir (2014) Tujuan muatan lokal adalah memberikan pengetahuan, ketrampilan kepada siswa, agar memiliki wawasan tentang keadaan daerah dan kebutuhan masyarakat sesuai nilai-nilai yang berlaku di daerahnya, dan dapat mendukung kelangsungan pembangunan daerah maupun nasional.

Muatan lokal pada kurikulum, dasarnya dilandasi oleh kenyataan bahwa Indonesia memiliki keanekaragaman adat istiadat, kesenian, bahasa, dan pola kehidupan yang diwariskan secara turun temurun dari nenek moyang bangsa Indonesia. kurikulum muatan lokal merupakan sekumpulan rencana pembelajaran yang terdapat komponen isi serta bahan pelajaran yang digunakan untuk penyelenggaraan kegiatan belajar dan mengajar yang ditetapkan oleh sekolah, sesuai dengan keadaan daerah tempat sekolah itu berada. Setiap tingkat satuan pendidikan dianjurkan untuk merencanakan mata pelajaran mulok pada sekolah. karena setiap daerah memiliki keragaman dan ciri khas budaya tersendiri. karagaman budaya tersebut merupakan aset yang harus dilestarikan agar tetap terjaga ciri khas daerahnya (Suryanti, dkk. 2018)

Berdasarkan penjelasan diatas perlu upaya untuk melestarikan dan mengembangkan kearifan lokal, agar bangsa Indonesia tidak kehilangan ciri khas potensi daerahnya. Upaya menjaga potensi daerah dapat dilakukan mulai dini dan kemudian diintensifkan secara formal melalui pendidikan sekolah 
dasar, sekolah menengah, hingga perguruan tinggi. Seni ukir Jepara misalnya yang telah menjadi potensi daerah Jepara yang harus dijaga kelestariannya melalui bidang pendidikan, dengan mengembangkan produk kurikulum muatan lokal seni ukir yang diharapkan mampu menjadi alternatif untuk mengenalkan seni ukir kepada generasi penerus, sehingga kelestariannya tetap terjaga.

Berdasarkan penjelasan yang telah disampaikan, penulis mengadakan penelitian yang berjudul "Pengembangan Kurikulum Muatan Lokal Seni Ukir di MTs Roudlotul Ulum Suwawal Jepara".

\section{METODE $\rightarrow$ Heading Level $1(11$ pts $)$}

Pengembangan kurikulum muatan lokal ini menggunakan model pengembangan pendekatan kompetensi, yang berpedoman pada model pengembangan yang dikembangkan oleh Toenlioe (2017). Pengembangan ini mengikuti enam langkah, langkah yang pertama adalah identifikasi kebutuhan lapangan kerja, pada langkah ini peneliti melakukan analisis kebutuhan (need assesment) terhadap potensi daerah. Setelah menganalisi kebutuhan lapangan, dilakukan penetapan standar kompetensi mata pelajaran yang mengacu pada hasil identifikasi kebutuhan daerah. Langkah selanjutnya adalah analisis tugas pelaku dunia kerja, kemudian pembuatan kerangka isi dan yang terakhir adalah pembuatan silabus (Toenlioe, 2017).

Dari model yang dikembangkan oleh Toenlioe, dapat digambarkan pada table sebagai berikut

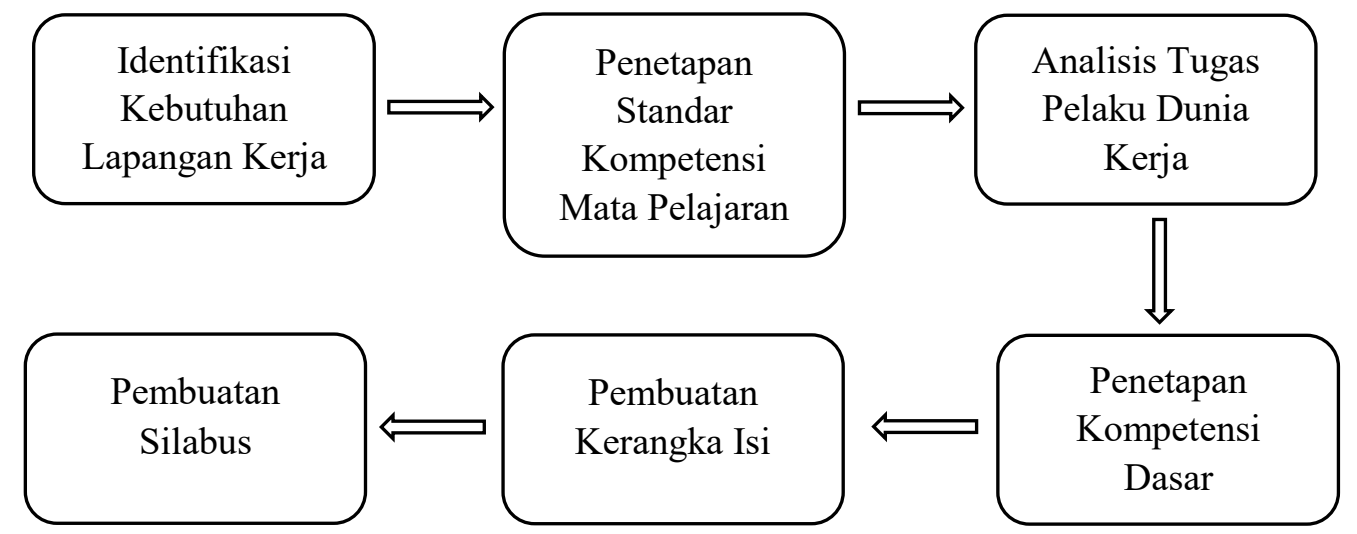

Gambar 1. Bagan model pengembangan kurikulum pendekatan kompetensi

Pengembangan kurikulum ini tidak dilakukan uji coba lapangan dan evaluasi, tapi pengembangan kurikulum hanya sampai berbentuk dokumen yang diuji kelayakan oleh ahli kurikulum dan ahli materi.

Jenis data yang digunakan adalah kualitatif dan kuantitatif. Data kualitatif yang dikumpulkan diperoleh dari hasil wawancara dengan beberapa sumber, seperti kepala sekolah, waka kurikulum dan pengrajin ukir. Data kualitatif ini berisi tentang saran, tanggapan, dan informasi dalam pengembangan kurikulum seni ukir. Data kuantitatif diperoleh dari hasil instrument ahli kurikulum dan ahli materi untuk mengetahui tentang kelayakan kurikulum muatan lokal seni ukir yang telah dikembangkan.

Uji coba ahli kurikulum muatan lokal seni ukir ini diberikan kepada ahli kurikulum dosen Teknologi Pendidikan UM. Uji coba ini dimaksudkan untuk menilai kelayakan kurikulum muatan lokal yang dikembangkan, apakah sudah sesuai dengan prinsip pengembangan kurikulum atau belum. Uji coba ahli kurikulum muatan lokal seni ukir ini diberikan kepada ahli materi yaitu pengrajin ukir. Uji coba ini dilakukan untuk menilai apakah materi yang digunakan sudah benar dan sesuai jika diajarkan dalam proses belajar atau belum.

Analisi angket tanggapan ahli materi dan ahli kurikulum menggunakan teknik presentase. Adapun rumus yang digunakan adalah:

1) Rumus untuk mengelola data per item 
Keterangan:

$$
\mathrm{P}=\frac{X}{X i} x 100 \%
$$

$\mathrm{P} \quad=$ Presentase

$\mathrm{X}=$ jawaban responden dalam satu item

$\mathrm{Xi}=$ Jumlah skor ideal dalam satu item

$\% \quad=$ Konstanta

2) Rumus untuk mengelola data keseluruhan

Keterangan:

$$
\mathrm{P}=\frac{\sum x}{\sum x i} x 100 \%
$$

$\mathrm{P} \quad=$ Presentase

$\sum x=$ Jumlah keseluruhan jawaban responden

$\sum x i=$ Jumlah Keseluruhan nilai ideal dalam satu item

Keterangan :

$>$ Jika kurikulum muatan lokal yang diujicobakan mencapai tingkat presentase $80 \%-100 \%$, maka muatan lokal tersebut layak digunakan.

$>$ Jika kurikulum muatan lokal yang diujicobakan mencapai tingkat presentase $60 \%-79 \%$, maka muatan lokal tersebut cukup layak digunakan.

$>$ Jika kurikulum muatan lokal yang diujicobakan mencapai tingkat presentase 50\% - 59\%, maka muatan lokal tersebut kurang layak digunakan.

$>$ Jika kurikulum muatan lokal yang diujicobakan mencapai tingkat presentase $0 \%$ - 49\%, maka muatan lokal tersebut tidak layak digunakan.

\section{HASIL}

Produk kurikulum yang dikembangkan berupa silabus dan RPP, berpedoman pada model pengembangan untuk melakukan analisis kebutuhan sebelum mengerjakan produk kurikulum, dan dilanjutkan dengan langakah-langkah selanjutnya mulai dari penetapan standar kompetensi, Analisis tugas pelaku, lalu penetapan kompetensi dasar, hingga pembuatan kerangka isi dan silabus.

Kurikulum muatan lokal ini selanjutnya divalidasikan kepada ahli materi dan ahli kurikulum. Pertama kurikulum ini divalidasikan kepada ahli materi yaitu pengerajin ukir dan guru seni, berdasarkan validasi yang dilakukan oleh ahli materi diketahui presentase kelayakan mencapai $90.13 \%$. hasil validasi ahli materi tersebut menunjukkan bahwa kurikulum muatan lokal seni ukir Valid.

Validasi yang kedua kepada ahli kurikulum yaitu dosen Teknologi Pendidikan Universitas Negeri Malang dan WAKA kurikulum. sedangkan untuk validasi kepada ahli kurikulum memperoleh presentase kelayakan mencapai $88.82 \%$. hasil validasi ahli materi tersebut menunjukkan bahwa kurikulum muatan lokal seni ukir Valid.

Setelah mendapat hasil dari data yang diolah menggunakan rumus diatas, kemudian hasilnya dicocokkan dengan kriteria kelayakan sebagai berikut:

\begin{tabular}{cccc}
\hline Kategori & Presentase & Kualifikasi & Nilai \\
\hline A & $80 \%-100 \%$ & Valid & 4 \\
B & $60 \%-79 \%$ & Cukup Valid & 3 \\
C & $50 \%-59 \%$ & Kurang Valid & 2 \\
D & $0 \%-49 \%$ & Tidak Valid & 1 \\
\hline
\end{tabular}

Gambar 2. Kriteria Validasi

Kurikulum yang dikembangkan berupa

\section{PEMBAHASAN}


Indonesia merupakan negara yang kaya, karena memiliki berbagai macam budaya, bahasa, dan kearifan lokal. Hampir setiap daerah di Indonesia memiliki potensi yang dapat dibanggakan, misalnya reog ponorogo, batik pekalongan, dan masih banyak lagi. Beberapa kebudayaan indonesia ditetapkan sebagai warisan budaya dari indonesia oleh UNESCO. Seiring berkembangnya zaman dan teknologi, minat para generasi muda mulai bekurang terhadap kebudayaan Indonesia (Wibawa, dkk. 2015).

Dalam sebuah penelitian Mukhlason (2016) seni hadrah yang dahulu sering dijumpai di kabupaten Pasuruan, kini sudah jarang ditemui ditengah kota Pasuruan. Hal tersebut disebabkan karena minat kaum muda kota Pasuruan terbuai oleh arus modernisasi perkembangan zaman sehingga mengancam warisan bangsa kita. Penelitian tersebut menunjukkan bahwa perkembangan zaman dapat mempengaruhi kaum muda yang mengakibatkan turunnya minat untuk mengenal budaya daerahnya sendiri

Potensi-potensi daerah tersebut harus dijaga dan diturunkan ke generasi selanjutnya, agar terjaga kelestariannya seiring perkembangan zaman. Indonesia saat ini kurang mengenal kebudayaan daerahnya sendiri. Hal ini, karena kuarang adanya himbauan dari pemerintah tentang pentingnya menjaga kelestarian budaya bangsa (Nisafani, dkk. 2014)

Menjaga potensi daerah dapat dilakukan melalui bidang pendidikan, yaitu dengan mengembangkan kurikulum muatan lokal. Kurikulum memiliki peranan yang sangan penting sebagai program pendidikan yang telah direncanakan secara sistematis, paling tidak tiga peranan kurikulum yang sangat penting, yakni peranan konservatif, peranan kritis atau evaluative dan peranan kreatif (Hamalik, 2017)

Dalam penelitian hidayanti, dkk (2018) Pendidikan dapat menumbuhkan karakter, dan karakter dapat mengupayakan peningkatan kepedulian terhadap lingkungan. Penguatan pendidikan karakter dapat mewujudkan kesadaran lingkungan dengan menciptakan lingkungan belajar yang ideal untuk pembelajaran dan kegiatan untuk menyadarkan siswa agar peduli lingkungan, sehingga dapat menumbuhkan tanggung jawab dalam pelestarian lingkungan. Penelitian Arifin, dkk (2018) juga menjadikan kurikulum muatan lokal sebagai upaya pelestarian seni karawitan yang sudah menjadi budaya jawa.

Penelitian yang dilakukan Meilani, dkk (2017) menunjukkan bahwa terdapat pengaruh bahan ajar muatan lokal terhadap sikap peduli siswa kelas V SD. Hasil penelitian menunjukkan nilai rata-rata posttest kelompok eksperimen dan kontrol sebesar 7,92 dan 75,96. Hasil uji-t dengan thitung sebesar 1,46 dan ttabel 1,671. Jadi thitung $<$ ttabel, sehingga dapat disimpulkan bahwa terdapat pengaruh bahan ajar muatan lokal konservasi fauna Bengkulu terhadap sikap peduli siswa Bahan ajar yang diberikan pada kelompok eksperimen memiliki pengaruh yang signifikan dengan thitung sebesar 2,79 dan ttabel 1,671. Hal ini menunjukkan bahan diolah secara baik, dengan menggunakan pesan persuasif, serta menarik bagi siswa sekolah dasar dapat pengaruh terhadap sikap peduli siswa.

Jepara adalah salah satu daerah yang terkenal dengan seni ukirnya. Seni ukir jepara juga potensi daerah yang harus dilestarikan, generasi-generasi pengrajin harus tetap ada agar seni ukir jepara tidak pudar dimakan zaman. Salah satu upaya untuk melestarikan adalah dalam dunia pendidikan, dengan dikembangkannya kurikulum muatan lokal sesuai potensi daerah. Oleh sebab itu penulis mengembangkan kurikulum muatan lokal seni ukir untuk jenjang MTs yang sudah teruji validitasnya oleh ahli kurikulum dan materi, penelitian ini dilakukan di MTs Roudlotul Ulum Suwawal Jepara. Hal tersebut di dukung oleh peraturan daerah jepara No 1 tahun 2011 terdapat pada pasal 26, bahwa satuan pendidikan harus menyusun serta mengembangkan kurikulum muatan lokal kabupaten yaitu ketrampilan ukir pada satuan pendidikan SMP/MTs.

Penelitian ini serupa dengan beberapa penelitian sebelumnya. Pratama, dkk (2018) menjelaskan bahwa tari boran merupakan kebudayaan lamongan yang harus di lestarikan, salah satunya melalui pendidikan, dengan membekali pengetahuan budaya yang disusun dalam kurikulum muatan lokal. Penelitian tersebut menghasilkan produk kurikulum muatan lokal tari boran yang telah teruji kelayakannya. 
Penelitian ini juga berhubungan dengan beberapa penelitian sebelumnya. Wicaksono, dkk (2018) muatan lokal dapat dikaitkan dengan kebutuhan daerah, potensi daerah dan ciri khas daerah setempat. Untuk mempermudah dalam memahami pelajaran muatan lokal peneliti mengembangkan media pembelajaran beupa suplement. Hal tersebut membuktikan bahwa muatan lokal sangatlah penting sehingga membutuhkan inovasi untuk mempermudah proses belajarnya, agar tujuan pembelajaran tersampaikan.

Ada beberapa prinsip umum dalam pengembangan kurikulum, yang pertama adalah prinsip relevansi, dalam relevansi ada dua macam yaitu relevansi dalam kurikulum itu sendiri dan relevan ke luar, yang kedua adalah prinsip fleksibilitas, ketiga kontinuitas, selanjutnya prinsip praktis dan yang terakhir efektivitas (Sukmadinata, 2017).

Kurikulum muatan lokal seni ukir yang dikembangkan berupa silabus dan RPP. Setelah pembuatan silabus dan RPP, produk kurikulum di ujikan ke layakannya kepada ahli kurikulum dan materi. Dan hasil yang diperoleh adalah $90.13 \%$ untuk ahli materi dan $88.82 \%$ untuk ahli kurikulum.

\section{SIMPULAN}

Jepara memiliki potensi daerah yaitu seni ukir hal ini perlu dilestarikan agar seni ukir jepara tetap terjaga. Salah satu bentuk untuk melestarikannya adalah dalam dunia pendidikan, dengan mengembangkan kurikulum muatan lokal. Kurikulum muatan lokal seni ukir bertujuan untuk mengenalkan kepada siswa terhadap kearifan lokal berupa seni ukir Jepara. Kurikulum muatan ini dikembangkan untuk siswa jenjang sekolah menengah pertama. Hal ini dikarenakan pada usia ini siswa dapat berpikir logis. serta siswa diharapkan lebih mudah memahami komponen-komponen yang ada pada kurikulum muatan lokal seni ukir Jepara.

Saran untuk pengembang selanjutnya diharapkan mampu mengembangkan lebih lanjut tentang kurikulum muatan lokal Seni Ukir Jepara. Hal yang berhubungan dengan materi perlu diperbaharui sesuai dengan perkembangan zaman untuk kedepannya. Kelengkapan kurikulum juga perlu diperhatikan oleh pengembang selanjutnya. Dari segi isi harus sesuai antara standar kompetensi, kompetensi dasar dan juga indikator yang terdapat didalamnya.

\section{REFERENSI}

Arifin, Z., Ulfa, S., \& Praherdhiono, H. (2018). Pengembangan Kurikulum Muatan Lokal Karawitan Sebagai Upaya Mengkonstruksi Pengetahuan dan Pelestarian Budaya Jawa di Jenjang SMA Jurnal Kajian Teknologi Pendidikan, 1(2), 123-132.

Budiani, K. N. (2018). Fasilitas Eduwisata Seni Ukir di Jepara. eDimensi Arsitektur Petra, 6(1), 281-288.

Hamalik, Oemar. 2017. Dasar-Dasar Pengembangan Kurikulum. Bandung: PT Remaja Rosdakarya.

Hidayanti, N., Abidin, Z., \& Husna, A. (2018). Implementasi Pendidikan Lingkungan Hidup Sebagai Kurikulum Muatan Lokal Ekopedagogi Dalam Membangun Karakter Siswa Di SDN Lowokwaru 2 Malang. Jurnal Inovasi Dan Teknologi Pembelajaran, 4(2).

Meilani, R., Noperman, F., Karjiyati, V., \& Karjiyati, V. (2017). Pengaruh Bahan Ajar Muatan Lokal Konservasi Fauna Bengkulu Terhadap Sikap Peduli Siswa Kelas V Sekolah Dasar Kota Bengkulu (Doctoral dissertation, UNIVERSITAS BENGKULU).

Mukhlason, M. (2016). Pengembangan Kurikulum Muatan Lokal Seni Hadrah Pasuruan. AT-Tahdzib: Jurnal Studi Islam dan Muamalah, 4(1), 1-20.

Muktadir, A. (2014). Pengembangan Model Mata Pelajaran Muatan Lokal Berbasis Kearifan Lokal Untuk Meningkatkan Karakter Di Sekolah Dasar Provinsi Bengkulu. Jurnal Pendidikan Karakter, (3).

Nangoy, O. M., \& Sofiana, Y. (2013). Sejarah Mebel Ukir Jepara. Humaniora, 4(1), 257-264. 
Nisafani, A. S., Muqtadiroh, F. A., \& Nugraha, N. F. (2014). Analisis dan Perancangan WikiBudaya dalam Rangka Melestarikan Budaya Bangsa dan Kearifan Lokal Nusantara. Jurnal SISFO, 5(2), 146-158. Pratama, I. K., Toenlioe, A. J., \& Ulfa, S. (2018). Pengembangan Kurikulum Muatan Lokal Tari Boran Sebagai Langkah Pelestarian Kebudayaan Lamongan Pada Jenjang Sekolah Menengah Pertama. Jurnal Kajian Teknologi Pendidikan, 1(2), 103-108.

Pratama, I. K., Toenlioe, A. J., \& Ulfa, S. (2018). Pengembangan Kurikulum Muatan Lokal Tari Boran Sebagai Langkah Pelestarian Kebudayaan Lamongan Pada Jenjang Sekolah Menengah Pertama. Jurnal Kajian Teknologi Pendidikan, 1(2), 103-108.

Sukmadinata,N.S.2017. Pengembangan Kurikulum Teori dan Praktik. Bandung: PT Rosdakarya

Suryanti, I., \& Hisri, T. B. (2018, July). Pendidikan Berbasis Kearifan Lokal Untuk Membangun Insan Kamil. In Prosiding Seminar Nasional Program Pascasarjana.

Toenlioe,A.J.E.2017. Pengembangan Kurikulum Teori dan Catatan Kritis. Bandung: PT Refika Aditama.

Wibawa, I. W. E. A., Arthana, I. K. R., \& Darmawiguna, I. G. M. (2015). Pengembangan Sistem Informasi Warisan Budaya Indonesia berdasarkan Metadata Standar International Committee For Documentation (CIDOC) Berbasis User Generated Content (UGC). Kumpulan Artikel Mahasiswa Pendidikan Teknik Informatika (ISSN: 2252-9063), 4(5).

Wicaksono, M. A., Sihkabuden, S., \& Husna, A. (2018). Pengembangan Media Pembelajaran yang Berupa Suplement Pada Muatan Lokal Khas Ngawi. Jurnal Kajian Teknologi Pendidikan, 1(2), 133-140. 